\title{
Prehistoric sorcerers and postmodern furries: Anthropological point of view
}

\author{
Barbora Půtová \\ Institute of Ethnology, Faculty of Arts, Charles University in Prague, Celetná 20, 11000 Prague 1, Czech Republic.
}

Accepted 1st August, 2013

\begin{abstract}
This paper provides an analysis of prehistoric art documenting the genesis of human creativity. The Upper Paleolithic saw creative rise of material technology as well as artistic creativity as documented by a wide range of artefacts. These artefacts probably depict prehistoric figures of sorcerers (shamans) who masked themselves as animals for their rites. At the same time these images can be interpreted as prehistoric sorcerers in masks descending into deep caves to take the symbolic step across the boundary dividing the world of people and animals, culture and nature. The article makes a comparison and selective analysis of prehistoric sorcerer images that are well preserved for example in the Upper Palaeolithic caves. Special attention is dedicated to the existence of sorcerers in postmodernism, in particular to the furry phenomenon - an anthropomorphous being with human behaviour and characteristics. The term furry is closely connected with aspirations of the people whose desire is to take on the appearance of an animal. They achieve this by putting on animal masks and costumes. The result is archetypal semiotic information documenting the dual substance of humanity - ancient union of the man and the animal.
\end{abstract}

Key words: Sorcerer, furry, Upper Paleolithic, postmodernism, identity, liminal being

\section{INTRODUCTION}

\section{UNEARTHLY BEINGS AND SORCERERS IN THE UPPER PALEOLITHIC}

The Upper Paleolithic gave rise to many works of art including paintings and engravings depicting unearthly beings integrating zoomorphous and anthropomorphous features. These beings can take the form of "anthropozoomorphs, therianthropes, or sorcerers." (Clottes and Lewis-Williams 1998) Their number today is not definite and it is estimated to be over seventy. These beings are usually interpreted to be Upper Paleolithic sorcerers who can be seen as Earth deities, Great Spirit or the Lord of the Animals. The anthropomorphous potential of sorcerers is often depicted with anatomic features of animals such as a bison, reindeer or deer.
Their animal sexual activity, fertility, vitality and strength are in some cases demonstrated with an erect phallus which is complemented with an animal tail. Some beings are even described as men's effort to set themselves apart from the strong matriarchal order and society in which they had submissive roles. The forms of fertilisation or integration of feminine/masculine and animal elements might represent symbolic exclusion of the woman from the man's world and thinking. However, the images of sorcerers can be also regarded as a shaman during a magical ritual that was significant for the community which used the cave. Religious rituals played a prominent role in the society as they consist of the "ability to enter into ecstatic states via a number of techniques and to create strong, emotionally binding 
relationships with other people" (Hayden, 2003).

"Wounded men" can also be included in the category of sorcerers. "Wounded men" are human figures of several lines radiating from their bodies depicted usually without the head, arms and bending forward which is probably meant to symbolize a physical reaction to the pain and cramps caused by altered states of consciousness. All of these "wounded men" are attributable generally to the Late Solutrean. Spears in their bodies might document their faith in sympathetic magic used in order to cause harm, damage or death. These wounds may also be explained in line with shamanism as shamans can be helped by spirits who can shoot their arrows at their victims. Another example is piercing of the shaman's body during his initiation when he or she acquires supernatural abilities and social status through suffering (Harner 1973, Leroi-Gourhan, 1982, Smith, 1992, LewisWilliams, 1997, 2002).

Many aspects of Upper Paleolithic art document that caves were used for shamanism and illustrate the ability to project introspective images on the surface. Furthermore, elements of cave art reflect the structure of the mind derived from internal feelings, dreams, memories, visions or altered states of consciousness. Prehistoric sites with cave art include shaman equipment, including percussion instruments, flutes made of bird bones and heel imprints indicating to ritual dances. The structure of the cave symbolizes a journey into unconsciousness and a lower (under)world, representing the shaman's inner journey. The Upper Paleolithic art mediated a relationship between opposite elements of the aboveground and underground and a boundary between conscious and unconscious aspects of the mind. The motifs illustrate a whole range of aspects from the shaman's practice including altered states of consciousness, rituals, terioanthropomorphous identity and animal powers. The mental world became materialized here and found its place in the universe. Natural environment, surfaces and cave structures, e.g. remote, silent, confined, hard to access and totally dark chambers (sensory deprivation or lack of oxygen), induced altered states of consciousness. The use of deep caves was taken to be a symptom of magical intent. Shamanismus could have played a crucial role in cognitive and social evolution as altered states of consciousness facilitated adaptation to ecologic and social changes in the Upper Paleolithic (Harner, 1982; Bahn, 2005; Whitley, 2009; Bahn, 2010).

\section{Unearthly beings and sorcerers in deep caves}

The oldest image of a sorcerer can be found in the Chauvet Cave (Ardèche), where there is a unique zoomorphous and anthropomorphous composition in the End Chamber. This composition dating back to the
Aurignacien is placed on a stalactite descending from the vaulted ceiling of the cave. It is a being called Sorcerer or Man-Bison (ca. $30000 \mathrm{BC}$ ), part human and part bison. At the end of the leg of the bison there are parallel lines hanging down. The body of the bison with a horned head is directed towards a vulva, a pubic triangle and two tapering legs of Venus that is being transformed in the back part of a feline (Clottes, 2003, 2008; Guthrie, 2005).

Three sorcerers are depicted in the French cave of Les Trois Frères (Ariège), which was discovered in 1904 after three boys - sons of the French prehistorian Henri Bégouën - fell into it. In Les Trois Frères there are long and narrow corridors leading to the Sanctuary, the heart of the entire cave system. What is of particular interest is the engraving called The Dancing Sorcerer called also The God of Les Trois Frères (ca. 14000 BC) over four meters above the ground level, only to be reached by a secret corridor climbing upwards in a spiral. On the engraving called The Dancing Sorcerer, which is 75 centimetres high and 50 centimetres wide, black colour was applied. It is made up of human legs and paws for hands, a deer-like face with exaggerated antlers, deer ears, owl eyes, tail of a horse or fox and human beard, penis and feet. His penis, while not erect, sticks out beneath his tail. He appears to be in some sort of dancing posture, ready to drop into a four-legged dance, balancing himself on bear-like forepaws (Breuil, 1952; Makkay, 1999; Ryan, 1999; Eshleman, 2003).

In the sanctuary there are two more sorcerers. What is of particular interest in the circular swirl of zoomorphous engravings in the Sanctuary is the picture of the second sorcerer referred to as The Small Sorcerer with a musical bow (Stone 2003). He seems to be herding the beasts and playing a musical bow - a primitive string instrument producing sounds that can induce ecstatic states. The bow is actually a sign having the form of a long, pointed loop attached to the nose or nostrils. The 30 centimetres high figure is a combination of anthromorphous and zoomorphous elements. He is bison-headed with a bisonhuman stomach and furry ridged back and human legs and feet. The Small Sorcerer rises up on his hind feet, one leg bent in stride, dance or prance. In front of this figure there is a hybrid animal with reindeer and bison hindquarters, whose open anus is emphasized (White, 2003). "The positioning and emphases concerning the hybrid animal and the bison-man suggest a chase involving human and animal coitus" (Eshleman, 2003). The third sorcerer also has a human bottom part, but his chest and turning head have morphologic features of a bison. The bottom part of his body is tapered into the human buttock and thigh. The sorcerer leaping forward has erection and testicles (Ruspoli, 1986). "The sorcerer of Les Trois Frères might well depot someone in a ritual animal costume, though it could equally have been intended to portray a god or a powerful spirit. It might even have been intended as a metaphorical portrait of an 
esteemed or powerful individual" (Stone, 2003).

The French cave of Le Gabillou (Dordogne), discovered in 1941, contains over 200 engravings (17 $000 \mathrm{BC}$ ). Le Gabillou is only made of an entrance chamber and a tunnel with zoomorphous and anthropomorphous engravings in the latter. At the end of the cave there is an engraving of a "wounded man" called The Sorcerer of Gabillou. The sorcerer, probably dancing, is dressed in an animal fur hiding his face under a bison or ox mask. Both his legs are bent. He holds his arms out in front of him and seems to have been struck by a spear. The horned and tailed figure is placed on the rock in front of a wide crack separating the sorcerer from a geometric composition of a rectangle and three vertical lines (Eshleman, 2003; Stone, 2003; Clottes, 2008, Clottes and Barbora, 2011).

A painting termed the Unicorn at the entrance to the Hall of the Bulls in the Lascaux Cave in Southwestern France can also be considered to be an unearthly being. It could be a mythical animal or a masked sorcerer. It is often interpreted as a Tibetan antelope or bull depiction in profile with two long horns emerging from its forehead and spotted body (Bataille, 1955). However, in Lascaux there are The Little Sorcerer and The Big Sorcerer in the Shaft. The Little Sorcerer is 40 centimetres high and it is a masked male hominid with a horse head. The Big Sorcerer looks like a sorcerer from Papua New Guinea, clad in a plaited-fiber costume. The most significant painting in the Shaft is The Bird-Headed Man falling backward in front of a charging bison with a bird on a stick and rhinoceros. The man appears to be dead or wounded. It is a hunting scene depicting an attacking animal that had just been struck into the stomach by a barbed shaft thrown by the falling man. The man's posture is stiff, his arms and hands spread. There is also a picture of a bird placed on a stick stuck into the ground and a circular sign under the body of the bull. Nearby there is also a picture of a rhinoceros standing with his back turned to the drama. The bird symbolism is also enhanced with the man's hands whose four fingers on each hand look like bird talons. The figure can be perceived as a bird from the waist down and as a human from the waist up. Moreover, the human head has features identical to those of the bird on the stick. Some believe that the bird-like head of the man is evidence of shamanism (Bataille, 1983; Mohen, 2002, Lewis-Williams 2002; Clottes, 2008).

In El Castillo, a Spanish cave not far from Altamira, the paleolithic artist used his imagination to improve natural shapes on the rock face. On the stalagmitic mass a vertical clay sculpture of a Bison-Man was drawn and engraved. The bison seems to have been oriented vertically and to the left. The backs of the rear legs, tail and dorsal line, are all indicated almost purely by the relief. The curve under the buttocks smoothly changes into firmly engraved human legs (Valladas et al., 2001;
Mohen, 2002; Lewis-Williams, 2007; Clottes, 2008). In the darkest part of the Saint-Cirq Cave (Dordogne) on the right bank of the Vézère River there is an engraving of an anthropomorphous being. The engraving of the socalled Sorcerer is some 50 centimetres high. His arms are held forwards and legs are bent. The Sorcerer's head is turned to the left and the feet to the right, in an almost fetal position, perhaps as a pregnant male. His whole body is complemented with his erect penis (LeroiGouran, 1982; Clottes, 2008).

The Kapova Cave (14000 BC) is a rock art site in the southern Ural Mountains of Russia. In this cave there is the Chaos Chamber with an anthromorphous being 35 centimetres high characterized with a distinctly bent body. Prolonged arms, bulging buttocks and bent knees enhance the impression that the human being is being transformed into an animal and is in the process of falling on all four limbs. Despite the absence of any characteristic sexual features it seems more likely to be that of a man than a woman (Clottes, 2008; Svoboda, 2011).

The motif of a "wounded man" is depicted in the Cougnac Cave in the Lot region of Southern France in the lower part of the chest of a large red megaloceros. A small black figure has three lines emerging from its lower back and buttocks. The head and upper parts of the body are not depicted. It appears to be running towards the right. In the same cave there is another figure of a "wounded man" painted inside the contour line of the head of a red mammoth. The body, which is depicted without arms and feet, is pierced on all sides by seven shafts. The "wounded man" motif can be also seen in the main chamber of the French cave Pech-Merle, some thirty kilometres away from the Cougnac Cave. The figure depicted here is pierced by eight shafts, but one of these may represent a penis. The figure has a bird head and very short arms (Mazet, 1956; Lewis-Williams, 2002; Clottes, 2008).

It has been 30, 000 years since people first started depicting strange beings whose bodies symbolised the duality of the man and the animal. It is remarkable that this motif has been accompanying mankind's pilgrimage until present. However, in postmodernism the beings integrating animal and human elements acquired a new dimension. Postmodern relativism and the desire to seize the human substance with alternative resources gave rise to a new type of a sorcerer - half man and half animal known as a furry.

\section{Sorcerers and unearthly beings in costumes of postmodern reality}

Having a variable and purposeful identity which is continuously formed and created became a part of postmodern reality. Any individual postmodern identity is procedural based on constant choice, search, 
configuration and representation. Every individual has to be responsible for updating their identity in accordance with how external conditions or their own intentions change. An identity here is a kind of an anthropologic constant, cultural construct and in particular a choice and process. Variability, changeability and the fact that it is hard to grasp also bring new meanings and possibilities. In postmodern context it is desirable to have an exactly defined identity as the more vaguely an identity is defined, the better for its holder (Cohen, 2004). Here "postmodern identity suggests a shift away from the notion of identity as stable, fixed and singular. Instead, identity is increasingly argued to be a shifting and fragmentary phenomenon, best characterised as an always-incomplete process rather than a finished outcome" (Jones, 2007).

Postmodern instability of identity gave rise to the furry ${ }^{1}$ phenomenon, representing an anthropomorphic animal, having human personalities and characteristics. A furry is generally an individual assuming a role of a particular animal and wears its costume (fursuit), some furries wear a partial fursuit consisting of ears and a tail. A furry is an animal being walking on two legs, with its anatomy it is similar to a human being having human intelligence or at least the ability of human speech. Furries often identify with, and/or assume, characteristics of a special/totem species of a nonhuman animal. Furries acquire identities such as dragon, feline (cat, lion or tiger) and canine (wolf, fox or dog) species or totally new species such as a chakan. Some furries create mixed species such as a fox and wolf (folf) or cat and rabbit (cabbit). People who assume the role of a furry a) are predominantly male, b) furries are generally young ${ }^{2}$, c) liked cartoons as children, d) enjoyed science fiction and e) most commonly selected wolves and foxes as their totem animals. However, there is no generally accepted set of rules and attributes that are ascribed to the furry phenomenon. What can be considered the only uniform factor is the combination of zoomorphous and anthropomorphous elements (Horowitz, 2007; Gerbasi et al., 2008).

The identity of a furry is expressed through a fursona representing its owner with the appearance and characteristics. Fursona may vary from a detailed image of the furry "self" to general aspects (colour of the fur, behaviour or animal body). However, a fursona does not have to exist at all. Furry may have a relation to an animal without having it defined in the form of a fursona. The decision whether a fursona will be created depends on every individual, although the creation of a fursona is usually unintentional. A furry may have several fursonas. A fursona may also evolve and take over moods and attitudes of its owner. At the same time the owner may receive some characteristics from the fursona (Caudron, 2006; Peachey, 2011).

In some cases, a furry has desire to become an animal - to embody into the fursona, a being whose appearance and characteristics the furry admires and aspires to obtain them. Sometimes a furry may feel to be an animal imprisoned in the human skin. Some furries felt like, or wished they were, a species of animal other than human. These feelings may lead to surgical interventions, corporal mutilation and cosmetic changes. The indulgence for imitating animals, whether animated or real, also affects sexual life. In direct contact or on the internet, members of the furry subculture indulge in conversations full of sexual innuendos (yiff), in sexual activities and objects evoking sexual arousal. Pictures and visualisation of anthropomorphous animals in human sexual positions was established in postmodern art as yiffy art (Reid, 2006).

A furry tries to be like its favourite figure in terms of physical appearance using costumes (fursuits) made of ears or paws or complex animatronic costumes. Fursuits are made of fabric, not of fur or animal skin. Their owners buy these costumes at furry conventions, on the internet, some make them themselves. Some furries put on fursuit other layers of clothes, e.g. they wear a red cocktail dress on a costume of a white leopard or blue jeans on a costume of a yellow dog. Costumes enable them to do something that they would not be able to do under common circumstances. The furry phenomenon is about creativity and freedom allowing you to choose what and who you are. People can be any being/animal that appears in comics, cartoons and films, advertisements, computer games or science fiction literature (Riggs, 2004).

A furry is identified with furry fandom - a rather broad community of the furry subculture and genre where furries get together, especially via internet sites. The furry fandom is made of internet fan subcultures whose members personally identify with nonhuman beings, such as animals, creatures of fantasy or cartoon characters. The furry fandom extends to many areas, including art, prose and the internet. Furries are able to create and sustain complex fictional personas in complex fictional worlds, and thereby create a real subculture in physical reality through the use of the mutability of the internet performance and presentation of self-hood. The furry fandom members are able to present themselves as possessing traits of previous and nonhuman lives (Jordan, 1999).

\section{SORCERERS AND UNEARTHLY BEINGS: COMPARING THE SHAMAN WITH THE FURRY}

Shamans have been gifted with healing, visionary and other spiritual skills. These people differ from other members of a community with the intensity of their feelings. Shaman practices are based on ecstatic behaviour and they are aimed at achieving, e.g. successful hunting, good weather and crop or healing an 
ill person. The shaman's ecstasy is perceived as a kind of altered state of consciousness. From this point of view, cave paintings are captured shaman visions of entering the supernatural world. The shaman has more than one soul and these souls leave the body in trance and set on a journey to other worlds. A part of shaman equipment include costumes, drums, masks or mirrors that help him to step across the profane space and approach the spiritual world (Bonin, 1976; Peters, 1980; Kalweit, 1987; Vitebsky, 2001; Eliade, 2004).

A furry acquires extraordinary abilities when entering the virtual reality in the form of a personal furry. The virtual space creates possibilities for constructing new identities that may provide more perceptual experiences, fantasies and illusions. Furries can change their own representation in cyberspace. Cyberspace opens to furries according to their needs and provides them ecstatic freedom. Furries discover new worlds, new life dimensions and at the same time they take on more identities, that is, souls. In the virtual as well as real world furries use fursuits to distinguish common life from the sacred and at the same time as the means for entering other dimensions. A real, animated or painted fursona can be regarded as a form of objectivisation of this world and identification with its rules (Ludlow, 1996).

The shaman is a liminal being - a sacral element that is in opposition to the profane community. It differs from his community through direct contact with sanctity, which he is also the embodiment of. One of essential elements of liminal beings is also minimization of sex distinctions. This element can be demonstrated through not distinguishing male and female participants of rituals or through eliminating the classification framework man woman. Another attribute is uniform clothing. This category may be extended by wearing a shaman costume representing something extraordinary when compared with clothes worn by other members of the community (Turner, 2005).

Furries play a liminal part in the majority society as it is a being experiencing and discovering unknown dimensions. Even their sexual identity does not have to be straight. Their costumes also contribute to this ambiguity as they document a different identity that cannot be classified and lies somewhere in between two genders. Furries in fursuits do not meet the criteria of the unity of sex, gender or sexual orientation. With their dresses they traverse the boundaries of the external world, they get rid of their limited form of being and meet the unknown, infinite and unseizable that changes them (Riggs, 2004).

The furry phenomenon in postmodern culture can be considered as return to original spiritual freedom of tribal societies. It is a kind of effort to transcend the present world reflecting the needs or desires to resign to new possibilities. The indefiniteness of cyberspace is near to transcendence that cannot be exactly defined, classified and its objective existence cannot be determined. Furries can achieve a special status here that differs from the majority society and they can discover and create new structures of life.

By comparing the status of a shaman and a furry we can describe and interpret (1) the similarity and versatility of different forms of spiritual liberation, (2) the feeling of mental transcendence and living through an exceptional experience, and (3) achieving an alternative success and meeting the needs in a society. Shamans living in traditional tribal societies had more than one soul, which enabled them to enter a supernatural world, where they got in contact with holiness. Postmodern furries enter the cyberspace, where they can, just as shamans do, generate different souls or take on different identities. Shamans and furries thus trespass the threshold of the profane world, though in different times, in order to modify their original personality and find new existential horizons of human feelings and cognition.

\section{REFERENCES}

Bahn Paul G (2010) Prehistoric Rock Art: polemics and progress. Cambridge: Cambridge University Press.

Bahn Paul G, Helvenston Patricia A. (2005) Waking the Trance Fixed. Louisville: Wasteland Press.

Bataille, Georges (1983) Die vorgeschichtliche Malerei: Lascaux oder die Geburt der Kunst. Stuttgart: Skira-Klett-Cotta.

Bonin, Werner Friedrich (1976) Lexikon der Parapsychologie und ihrer Grenzgebiete. Bern: Scherz Verlag.

Breuil Henri (1952) Quatre cents siècles d'art pariétal. Montignac: Centre d' Etudes et de Documentation Prehistoriques.

Caudron Shari (2006) Misfit furries: Who are you people? Fort Lee: Barricade Books.

Clottes, Jean (2003) Chauvet Cave: The Art of Earliest Times. Salt Lake City: University of Utah Press.

Clottes, Jean (2008) Cave Art. New York: Phaidon Press.

Clottes, Jean, Lewis-Williams, James David (1998) The Shamans of Prehistory: Trance and Magic in the Painted Caves. New York: Harry N. Abrams.

Clottes JP, Barbora SV (2011) Pravěké umění: evoluce člověka a kultury. Praha: AVS.

Eliade, Mircea (2004) Shamanism: Archaic Techniques of Ecstasy. Princeton: Princeton University Press.

Eshleman, Clayton (2003) Juniper Fuse: Upper Paleolithic Imagination and the Construction of the Underworld. Middleton: Wesleyan University Press.

Gerbasi, Kathleen C., Bernstein, Penny L. et al. (2008) 'Furries from A to Z (Anthropomorphism to Zoomorphism)', Society and Animals 16: 197-222

Guthrie R Dale (2005) The Nature of Paleolithic Art. London: University Of Chicago Press.

Harner Michael (1982) The Way of the Shaman. New York: Bantam.

Hayden, Brian (2003) Shamans, Sorcerers and Saints: A Prehistory of Religion. Washington: Smithsonian Books.

Horowitz Alexandra C, Bekoff Marc (2007) 'Naturalizing Anthropomorphism: Behavioral Prompts to our Humanizing of Animals', Anthrozoös 20: 23-35

Jelínek Jan (1977) Velký obrazovky atlas pravěkého člověka. Praha: Artia.

Jones Elizabeth Houston (2007) Spaces of Belonging: Home, Culture and Identity in 20th-Century French Autobiography. Amsterdam: Rodopi.

Jordan Tim (1999) Cyberpower: The Culture and Politics of Cyberspace 
and the Internet. London: Routledge.

Kalweit Holger (1987) Shamans, Healers and Medicine Men. Boston: Shambhala.

Lewis-Williams James David (1997) 'Harnessing the Brain: Visions and Shamanism in Upper Palaeolithic Western Europe', in Conkey, Margaret W., Soffer, Olga et al. (eds) Beyond Art: Pleistocene Image and Symbol, pp. 321-42. San Francisco: California Academy of Science.

Lewis-Williams James David (2002) The Mind in the Cave. London: Thames and Hudson.

Leroi-Gourhan André (1982) The Dawn of European Art: An Introduction to Palaeolithic Cave Painting. New York: Cambridge University Press.

Ludlow Peter (1996) High Noon on the Electronic Frontier: Conceptual Issues in Cyberspace. Cambridge: MIT Press.

Makkay János (1999) Two Studies on Early Shamanism. Budapest: Magánkiad.

McCully RS (1984) 'Sorcerers as Masculine Protest Symbols in Upper Paleolithic Times', J. Psychoanalytic Anthropology 7: 366-378.

Méroc Louis, Mazet Jean (1956) Cougnac: Grotte peinte. Stuttgart: Kohlhammer.

Mohen Jean-Pierre (2002) Prehistoric Art: The Mythical Birth of Humanity. Paris: Pierre Terrail.

Peachey Peachey, Childs Mark (2011) Reinventing Ourse/ves: Contemporary Concepts of Identity in Virtual Worlds. London: Springer-Verlag.

Peters Larry G, Price-Williams Douglass (1980) 'Towards an Experiential Analysis of Shamanism', American Ethnologist 7: 398418.

Reid Luc (2006) Talk the Talk: The Slang of 65 American Subcultures. Ohio: Writer's Digest Books.

Riggs Adam (2004) Critter Costuming: Making Mascots and Fabricating Fursuits. Roseville: Ibexa Press.
Ruspoli Mario (1986) Lascaux: Heiligtum der Eiszeit. Freiburg im Breisgau: Herder Verlag.

Ryan Robert E (1999) The Strong Eye of Shamanism: A Journey into the Caves of Consciousness. Rochester: Inner Traditions.

Smith Noel W (1992) An Analysis of Ice Age Art. New York: Peter Lang. Stone Alby (2003) Explore Shamanism. Loughborough: Explore Books.

Svoboda Jiří A (2011) Počátky umění. Praha: Academia.

Turner Victor (1995) The Ritual Process: Structure and Anti-Structure. Hawthorne: Aldine Transaction.

Valladas HTL, Nadine CH (2001) 'Radiocarbon AMS Dates for Paleolithic Cave Paintings', Radiocarbon 43: 977-986

Vitebsky Piers (2001) Shamanism. University of Oklahoma Press: Norman.

White Randall (2003) Prehistoric Art: The Symbolic Journey of Humakind. New York: Harry N. Abrams.

Whitley David S (2009) Cave Paintings and the Human Spirit: The Origin of Creativity and Belief. Amherst: Prometheus Books.

Wosien MG (1974) Wosien: Sacred Dance: Encounter with the Gods. London: Thames \& Hudson.

\section{Notes}

${ }^{1}$ Equivalent terms include funny animal, talking animal or kemono in Japan, although there are subtle differences in the meaning of each of these terms.

${ }^{2}$ More than 90 percent of furries to be aged 15 to 34 . 